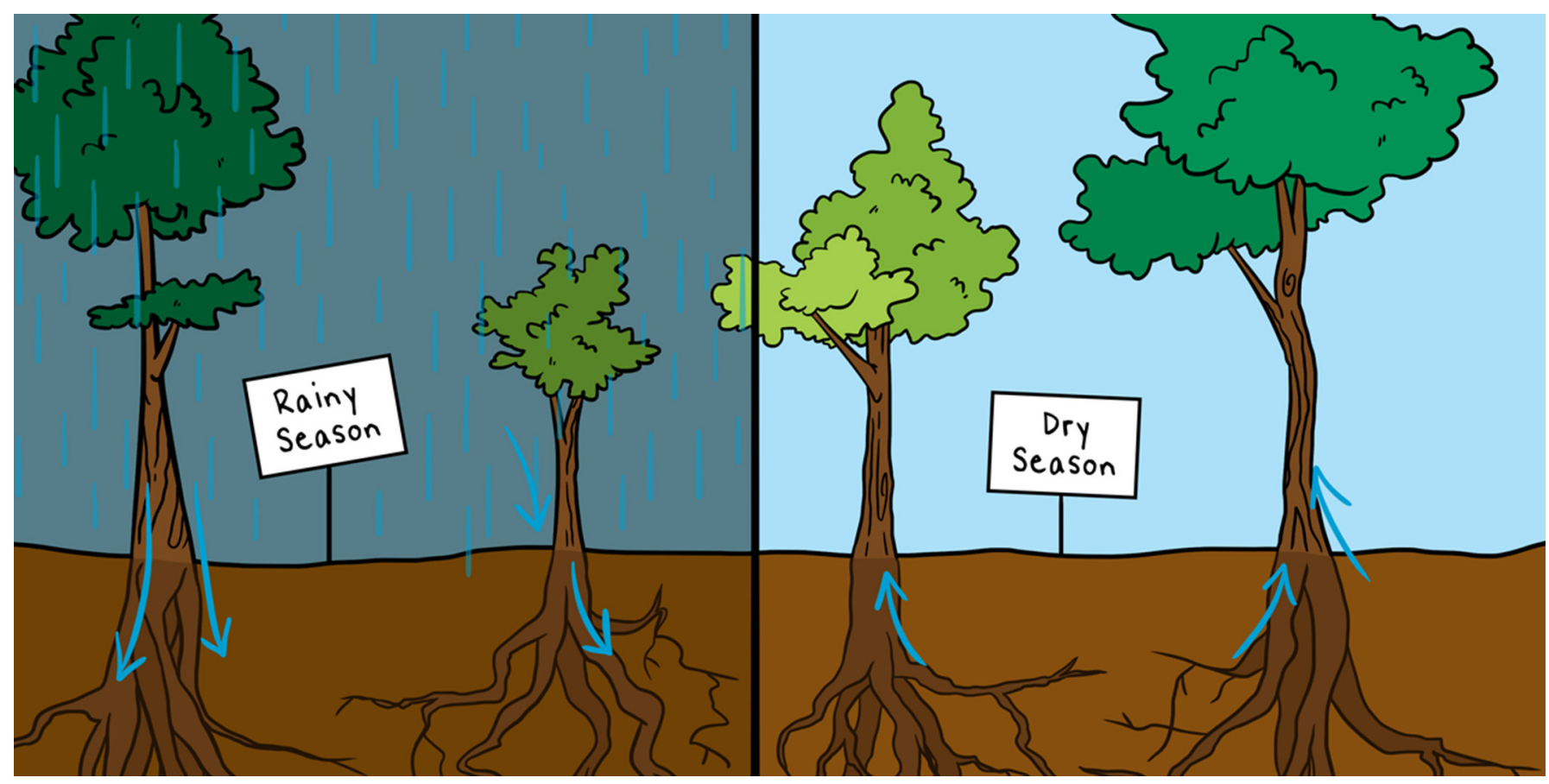

\title{
CAN TREES HELP PUT WATER BACK INTO THE SOIL?
}

\section{Kelly Cristina Tonello ${ }^{1^{*}}$ and Julieta Bramorski ${ }^{2}$}

${ }^{1}$ Research Group of Forest Hydrology Ecosystems, Department of Environmental Science, Federal University of São Carlos, Sorocaba, Brazil

${ }^{2}$ Research Group of Forest Hydrology Ecosystems, Department of Environmental Science, Federal University of Amapá, Macapá, Brazil

YOUNG REVIEWER:

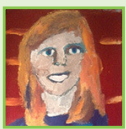

ANNA-MARIE

AGE: 16

\section{BIOME}

They are types of ecosystems, habitats or biological communities with a certain level of homogeneity.
Just to the south of the Amazon, there is a vast and biodiverse savanna that scientists believe is under even greater threat, called the Cerrado. Scientists want to understand how the plants that live in the Cerrado affect the rainfall that enters the ground to recharge the aquifer. Many of these plants are trees that capture rainwater and drain it down their bark-covered branches and trunks. This water, called stemflow, may be one way to recharge the aquifer, if the branches and bark of the trees are the right size and shape. This article will introduce the common plant species of the Cerrado, describe how they affect the way rainfall enters the ground, and discuss how bark and branches may help conserve water.

\section{DO YOU KNOW THE CERRADO?}

The Cerrado originated at least 40 million years ago, making it one of the oldest biomes on Earth. The Cerrado is huge, originally covering $22 \%$ of Brazil, and it contains the highest biodiversity of any biome in 
Figure 1

The Cerrado forest is also called the "upside-down" forest Notice how the tree roots go much deeper into the soil than their canopies reach to the sky! Figure credit: Dr. John Toland Van Stan, II.

\section{WOODY PLANTS}

Forest species providing products such as wood.

\section{AQUIFER}

An area that can store or transmit water underneath the ground.

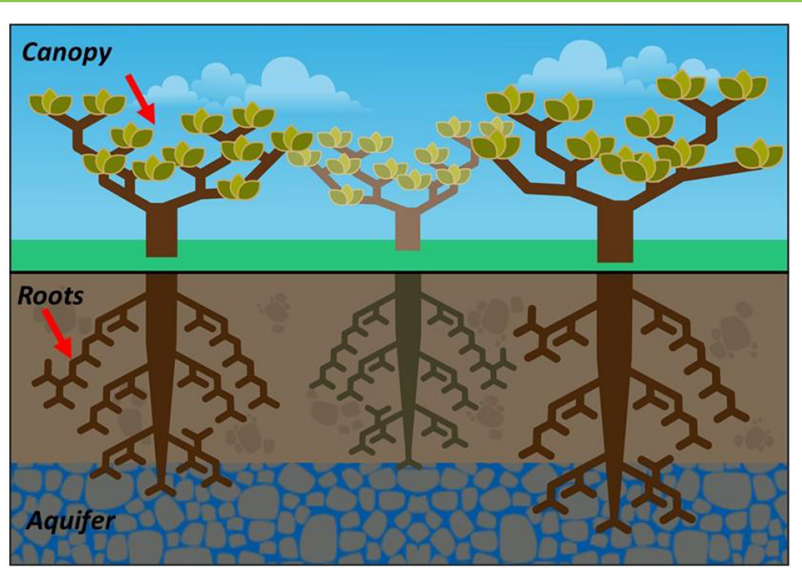

Figure 1

Brazil. The Cerrado isn't the same over its entire area; instead, it is a patchwork made of different types of land cover, including cerradão ("big cerrado"), typical cerrado, campo cerrado, dirty cerrado field, and clean cerrado field. The cerradão is the only type of land in the Cerrado with large forests. There is a great diversity of plants in the Cerrado, including palm, fruit, and timber trees, plus a wide variety of grasses, bromeliads (like mini pineapples), orchids, and other smaller plants. Some species, like timber trees, have twisty and thick trunks reaching up to 20 meters in height. Other woody plants are shorter and more like bushes, like the strawberry guava.

This diversity of plant life is surprising because the Cerrado has a dry season every year that can last from April to September and the soils are generally low in nutrients. Scientists believe that many trees survive the long dry seasons in poor soils due to their deep root systems: some roots can reach up to 15 meters in depth. This allows them to capture water from natural water storage areas called aquifers, deep below the surface. The rainwater that flows through this huge savanna contributes water to the Guarani aquifer, which is important to many countries in South America. Many measurements and estimates suggest that the height of the tree canopy above the ground is only a third of distance that the roots extend into the soil. Because its root system can be more extensive than its treetops, the Cerrado is also called the "upside-down forest." So, the Cerrado's upside-down forest is strongly rooted into the aquifers below it (Figure 1).

\section{HOW TREES HELP TO RECHARGE AQUIFERS}

Plant roots take up lots of water from the Cerrado's aquifers during the dry season. But they also help to put lots of water back into these aquifers later. You see, the climate of the Cerrado also has a rainy season, which generally occurs between October and February. The aquifers are recharged by this rain, but they depend on plants to get the rainwater down into them. The same plant roots that remove 


\section{STEMFLOW}

Water that is captured by plant leaves and branches and drained down their stems.

\section{ARID AND}

SEMI-ARID REGIONS

Regions where the rain is usually short-lived but very intense. groundwater from the aquifers during the dry season provide drainage pathways for rainwater into and through soils during the rainy season. These root pathways can help rainwater to drain into and recharge the aquifers. In fact, if we looked closely at one of these plants, we could count thousands or even millions of roots-that's thousands to millions of pathways for rainwater to travel along to recharge the aquifers! And, if we look for tiny roots with our microscopes, we will see countless other mini-root water pathways that intertwine with the roots of other plants [1]. So, the Cerrado's complex root system can promote water movement from the soil surface to the aquifers in the wet season, while also nourishing the plants in the dry season.

\section{RAIN MUST OVERCOME LEAFY AND BARKY OBSTACLES}

The story of roots and aquifers is a little more complicated though, because a lot happens to rainwater between the Cerrado's treetops and the soil surface. When the rain reaches the forest's leaves and bark, it is forced along one of three paths... and not all of them lead to the soil surface! First, some water will be stored on leaves and bark and will eventually evaporate back into the air. Second, some water will drip to the surface, as if a branch has become a leaky faucet. Finally, some rain will stick to the bark, branches, and stems and will drain all the way down to the soil surface at the bottom of the tree trunk. This last process is called stemflow. Stemflow comes from many branches all draining down to one spot at the surface right next to the trunk, so it can result in a very concentrated flow of water to the soil in that location. Stemflow does not just come from rain. In fact, in some arid and semi-arid regions where there is little rainfall, water vapor from the air condenses into liquid water when it contacts the plant and drains to the soil via stemflow.

Many researchers are now trying to understand what factors affect the production of stemflow in the Cerrado and in many other regions around the world. Stemflow depends on how the forest is structured, such as the number of trees in a certain area and the types of plant species present. For example, forests with a larger density of trees and a greater area of leaves and bark tend to catch a greater amount of rainfall that becomes stemflow. Sometimes, the structure of a plant's leaves can reduce the amount of stemflow, for example if they are hairy. In those cases, the leaves may retain the water, which will eventually evaporate and not make it to the soil. The way a tree species' bark is shaped is also important. There are many types of bark in the Cerrado. A thicker bark (Figures $2 \mathrm{~A}-\mathrm{C}$ ) could reduce stemflow by acting like a sponge and sucking up all the water draining down the trunk. A thinner bark (Figures 2D-F) would not absorb as much water, allowing more stemflow to reach the ground. 
Figure 2

Examples of bark types from the Cerrado.

Notice how the top row of trees has thick bark that can absorb some of the stemflow, while those in the bottom row have thinner bark that would allow more stemflow to reach the soil. (A) candeia, (B) cedro, (C) angico, (D) palm, (E) pata de vaca, (F) ipê amarelo.

\section{LITTER}

Is the layer composed by the deposition of plant remains (leaves, branches) and the accumulation of organic material in different stages of decomposition that superficially covers the soil.
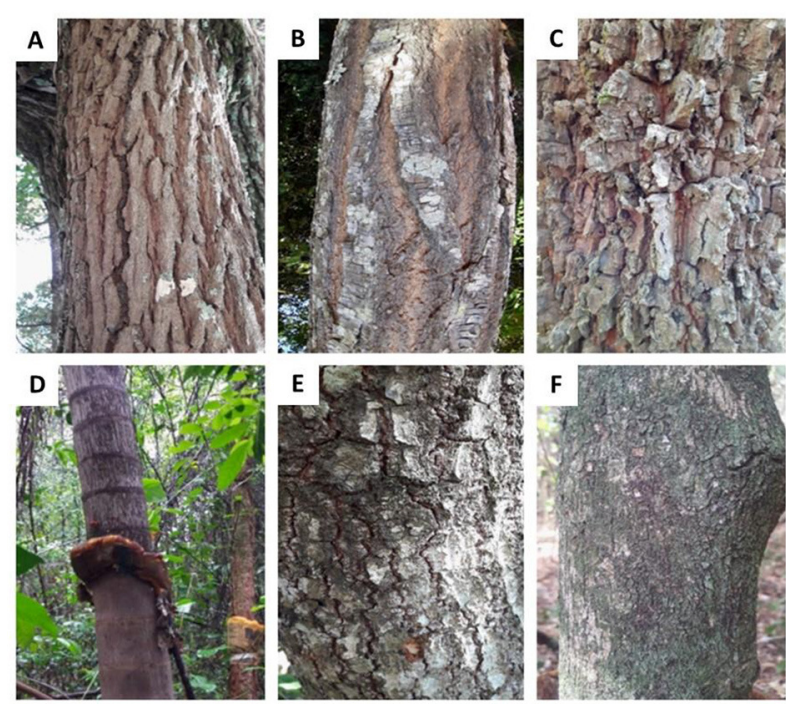

Figure 2

\section{THE FINAL HURDLE: CROSSING THE LITTER}

Upon reaching the bottom of the trunk, stemflow may still not meet the soil quite yet...it might instead meet the litter, a thick layer of fallen leaves, branches, insects, flowers, fruits, and even fallen tree bark, too! This litter can protect the water that makes it into the soils below, blocking soil water from the wind and sun that could cause it to evaporate. Some researchers have found that stemflow can pass right by the litter layer and into the soils. If this is common, then stemflow may make it to the soils and the protection of the litter layer by riding the bark straight into the soils. In the Cerrado, more water has been found in soils that lie beneath the forest litter. So, maybe the bark does a double duty! First, it helps to drain rainwater along stems and into the soils. Then, perhaps the fallen bark in the litter helps protect the water that makes it to soils, allowing it to infiltrate and recharge the aquifers!

\section{THE MAGNIFICENT UPSIDE-DOWN FOREST}

The upside-down forests of the Cerrado, with their large roots and trees with thick and rugged bark, have been fittingly called a "cradle of waters." We hope that you now have a better understanding of forest and water relation. It is important for researchers to continue to study forest hydrology because we have a lot of specific interactions among biomes, their structure, soil properties and hydrology. Further research will help us to understand and protect Cerrado forests in South America. So, we wish someday we can count on your help to study and protect this magnificent biome! 


\section{ACKNOWLEDGMENTS}

The authors would like to thank the young reviewer and John T. Van Stan, II for assistance with the illustrations. Part of this work was made possible due to funding from the Brazilian National Council for Scientific and Technological Development (CNPq) and International Paper Co., Brazil.

\section{REFERENCES}

1. Fellet, J. 2020. Como as Raízes do Cerrado Levam Água a Torneiras de Todas as Regiões do Brasil. Available online at: https://www.bbc.com/portuguese/brasil -39391161 (accessed March 17, 2017).

SUBMITTED: 30 July 2020; ACCEPTED: 21 May 2021; PUBLISHED ONLINE: 23 June 2021.

EDITED BY: John T. Van Stan, Georgia Southern University, United States

CITATION: Tonello KC and Bramorski J (2021) Can Trees Help Put Water Back Into the Soil? Front. Young Minds 9:589362. doi: 10.3389/frym.2021.589362

CONFLICT OF INTEREST: The authors declare that the research was conducted in the absence of any commercial or financial relationships that could be construed as a potential conflict of interest.

COPYRIGHT (c) 2021 Tonello and Bramorski. This is an open-access article distributed under the terms of the Creative Commons Attribution License (CC BY). The use, distribution or reproduction in other forums is permitted, provided the original author(s) and the copyright owner(s) are credited and that the original publication in this journal is cited, in accordance with accepted academic practice. No use, distribution or reproduction is permitted which does not comply with these terms.

\section{YOUNG REVIEWER}

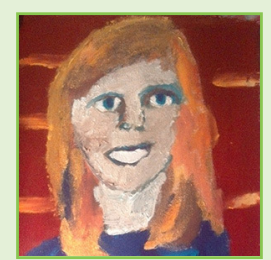

\section{ANNA-MARIE, AGE: 16}

My favorite subject is biology, I like bionics. In the future I would like to work on new materials, new substances. I am curious about the mysteries of the universe, there is so much to discover!

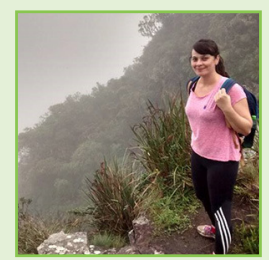

\section{AUTHORS}

\section{KELLY CRISTINA TONELLO}

I am an Associate Professor at the Federal University of São Carlos and a head of the Research Group of Forest Hydrology Ecosystems - Sorocaba Core (Hidrolef-Sorocaba). My research focuses on how forests are linked with the water 


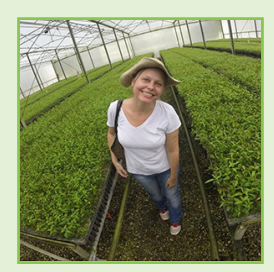

cycle and soil water content. Besides research, I also enjoy being out in nature, doing adventure tourism, climbing mountains, and visiting places that I have never been before. *kellytonello@ufscar.br

\section{JULIETA BRAMORSKI}

I am an Associate Professor at the Federal University of Amapá and the head of the Research Group of Forest Hydrology Ecosystems - Macapá Core (Hidrolef-Macapá). My research focuses on understanding how the presence of the forest acts in the conservation of ecosystems. Besides research, I also enjoy to listening a music and watching movies. 